\title{
The scientific diplomat
}

A physician and Nobel-prizewinning chemist at Johns Hopkins University in Baltimore, Maryland, Peter Agre has never shied away from politics. In 2007 he briefly considered running for the US Senate; in 2009 he became president of the American Association for the Advancement of Science (AAAS) and, with the association's Center for Science Diplomacy, began to engage with some of his country's bitterest political enemies. Over a shaky mobile-phone line from rural Zambia, where he is assisting efforts to combat malaria, Agre spoke to Nature about his recent visits to Cuba and North Korea.

\section{How do you pick the countries to visit? We decide on countries where we think we could do better than our elected officials. We choose obvious nations, where we have everything to gain and nothing to lose, just to see how we can help them to develop peaceful science.}

\section{Where exactly did you go?}

In Cuba, we visited the Center for Genetic Engineering and Biotechnology, the Finlay Institute for vaccine research and production, the University of Havana, the Latin American School of Medicine and the Cuban Academy of Sciences, all in Havana. North Korea granted visits to all the institutions that we asked to see, including the State Academy of Sciences' biology and biotechnology branches, Kim Chaek University of Technology in Pyongyang and Pyongyang University of Science and Technology. I have to be careful not to oversell. We met with officials, not with graduate students to watch them do experiments. The goal is to make it interesting so that we can continue the exchange. There was some scepticism on their part. They have watched US policy change, warm up and cool down over previous presidential terms.

\section{How strong is science in Cuba and North Korea?}

Both countries are trying hard to boost science, but the level is difficult to establish. Both had beautiful computing centres, as good as I see at most US universities. In Cuba, they had excellent English and were highly motivated. They seem to have had large success in raising vaccines to infectious diseases. They also seem to have excellent public-health networks, and disease prevention is a priority. I sense that the [US trade] embargo has strongly inhibited sophisticated science.

North Korea has tremendous intellectual horsepower and could develop fast. Stuart Thorson [who directs an informationtechnology collaboration between Syracuse
University in New York and Kim Chaek University of Technology] says that undergraduate teams performed well in international undergraduate computerprogramming competitions. The level of science is variable. They seem to have large success in computer-information systems; we toured some biological labs that were modest. Central heating was lacking. The DPRK [Democratic People's Republic of Korea] is a poor country, and capital investment in laboratories and basic amenities is needed. There was some talk of stem-cell and cloning research, but I'm not aware of whether they are achieving success. We would need to see more. It cannot help that they have such limited access to outside information.

\section{Were you restricted? Could you discuss controversial topics, for example nuclear weapons?} We couldn't run the streets. And we avoided controversial topics. In both countries a few private opinions were shared, and their viewpoints seemed very reasonable.

In North Korea, four individuals from the State Academy of Sciences accompanied us everywhere outside the hotel. Some people ask if we felt safe in North Korea; I wish I could feel that safe in Baltimore. Exchanges were free, and there were discussions of family and personal interests. The fear of Americans could easily evaporate with more positive contacts. Their isolation is really extreme, and most of our science contacts admitted that they had never met Americans before.

In Cuba, a tour-group leader and interpreters travelled with us, but we were not restricted. Free exchanges and visits with shopkeepers and others in restaurants occurred. We stayed away from controversial issues.

\section{What's the next step?}

The next step with Cuba will be more visits - Cubans to the United States and Americans to Cuba. Increased interactions

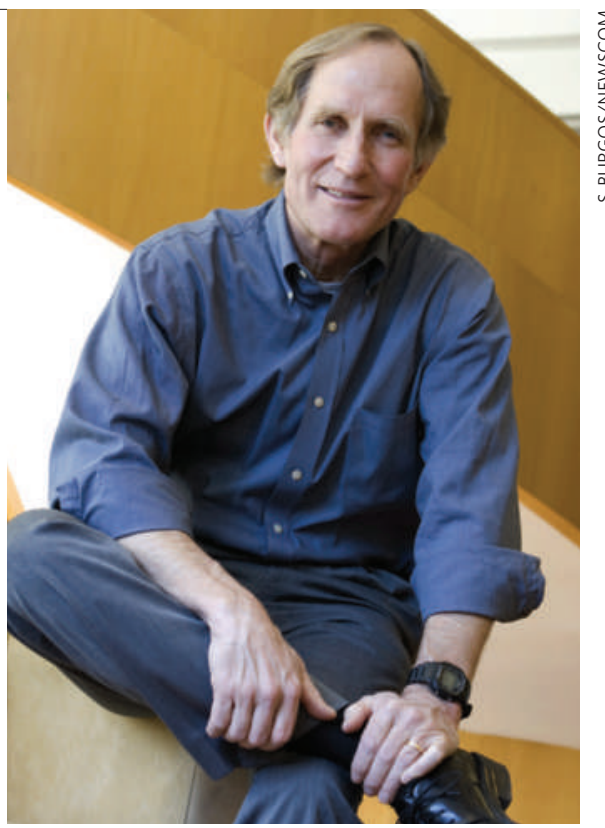

in Europe or other locations should also be expected. Until the US government changes its policy towards Cuba, we need to be careful that we remain focused on the science and do not delve into the policy arena without a portfolio for doing so. Areas of future exchanges may include public health, disaster preparations and agriculture. With regard to North Korea, the next step will occur when the State Academy of Sciences approves an agreement to pursue collaborations. More visits to North Korea and to the United States, and contacts during activities in other countries, are anticipated. We cannot rush North Korea any more than we can rush the US government. Areas of future exchanges may include pharmaceutical manufacture, digital-library access, information systems and agriculture.

\section{What other countries are on the radar for the AAAS?}

Syria, Rwanda and Myanmar. [David Baltimore, Agre's predecessor as AAAS president, made exploratory visits to Syria and Rwanda, and follow-up exchanges are under way. A mission to Myanmar is planned for 2010.]

\section{What do you hope will come out of this? I imagine it is like the situation 30 years ago when China was still isolated. Now it's hard to imagine life without China. And science could be the path to political peace. In the 1950s, it helped a lot to have scientists in the Soviet Union and the United States talking to each other.}

Interview by David Cyranoski. 